\title{
Food and Biosecurity: Livestock production and towards a world free of foot-and-mouth disease
}

\author{
Tom Kompas ${ }^{\mathrm{a}, \mathrm{b}^{*}}$, Hoa Thi Minh Nguyen ${ }^{\mathrm{a}}$, Pham Van $\mathrm{Ha}^{\mathrm{a}}$ \\ ${ }^{a}$ Crawford School of Public Policy, Crawford Building (132), Lennox Crossing, Australian National \\ University, Canberra, ACT 2601, Australia \\ ${ }^{b}$ Centre of Excellence for Biosecurity Risk Analysis, University of Melbourne, Melbourne, 3010 Australia
}

\begin{abstract}
A key challenge for global livestock production is the prevalence of infectious animal diseases. These diseases result in low productivity in meat and diary production, culled animals, and significant barriers to trade and lost income for meat and meat products. Foot-and-mouth disease (FMD) affects both developing countries, where it is often endemic and very costly, and developed countries where incursions result in considerable economic losses in the order of billions of dollars per year. In some cases, production levels of pork meat in developed countries have still not recovered to levels prior to past disease incursions, more than a decade ago. In developing countries, the export of animal products has exhibited sluggish growth for decades, constrained by ongoing animal disease problems. We make three contributions. First, we provide an overview of worldwide meat production, consumption and trade in the context of FMD. Second, we provide insights into the economics of biosecurity measures and how these activities should be optimally designed to enhance livestock production. Third, we analyse a case study of an FMD-endemic country, Vietnam, which has been trying to achieve FMD-free status for some time. Lessons learnt from this case study shed light on the challenges in achieving FMD-free status in developing countries, which in its useful for a global FMD control strategy and the promotion of world food security.
\end{abstract}

Keywords: livestock production, trade, biosecurity, foot-and-mouth disease, Vietnam

Acknowledgements: Thanks to Dr. Van Dang Ky, Department of Animal Health, Vietnam, for valuable comments. Partial funding from the Centre of Excellence for Biosecurity Risk Analysis at the University of Melbourne is also greatly appreciated.

\footnotetext{
* Corresponding author.

Email addresses: tom.kompas@anu.edu.au, tom.kompas@unimelb.edu.au (Tom Kompas),hoa.nguyen@anu.edu.au (Hoa Thi Minh

Nguyen),ha.pham@anu.edu.au (Pham Van Ha)
} 


\section{Introduction}

Population growth and rapid urbanisation has put enormous pressure on the livestock sector. This sector has grown exponentially to meet the demands of an additional 3.2 billion people as well as an increase of $56 \%$ in the world meat consumption over the last four decades (FAO, 2014; Alexandratos and Bruinsma, 2012). This exponential growth has been largely attributed to the rapid development of intensive production systems and, to some extent, trade liberalisation, which has increased meat supplies available throughout the world at cheaper prices (FAO, 2013). A key constraint to this growth is the incursion and spread of trans-boundary animal diseases (TADs). These diseases can severely disrupt regional and international trade, resulting in world supply shortages, a substantial drop in herd sizes and production, and a fall in overall consumption (Morgan and Prakash, 2006; OIE and FAO, 2012; Knight-Jones and Rushton, 2013).

Among TADs, foot-and-mouth disease (FMD) is considered as 'one of the most contagious animal diseases' (OIE and FAO, 2012). FMD is a highly contagious viral disease affecting cloven-hoofed animals. Although most infected animals recover, FMD has debilitating effects, including substantial losses in weight and milk production (Grubman and Baxt, 2004). In addition, the FMD virus can rapidly replicate and spread via various pathways and stay in recovered animals (as carriers) for a long period of time (GAO, 2002; Grubman and Baxt, 2004; Condy et al, 1985). For these reasons, FMD is on List A of the World Organisation for Animal Health (OIE) list of diseases, thereby preventing countries with FMD from accessing international food export markets (Leforban, 1999).

FMD is endemic mostly in developing countries. It is prevalent in two thirds of the world, but its impact is not only in countries where it is epidemic, but also on FMD-free countries. Over the last 15 years, FMD has caused a loss of over US\$ 25 billion in countries that were previously free of FMD (Knight-Jones and Rushton, 2013), despite aggressive prevention measures taken at ports of entry. Partly for this reason, a global FMD control strategy was launched in 2012 , officially recognising that reducing FMD at source in FMD-endemic countries is 'a shared interest and should be considered a global public good' (OIE and FAO, 2012).

Key to the success of the global FMD control strategy, especially in light of increasing globalisation, is not only enhanced biosecurity measures (e.g., border quarantine, movement controls and local surveillance), but progress in controlling and eradicating FMD in endemic countries (OIE and FAO, 2012). Nonetheless, little hard information is available on country experience in the fight against endemic FMD. Existing literature has largely focused on the economic losses of FMD incursions in countries which were previously free of the disease (Knight-Jones and Rushton, 2013) ${ }^{1}$. Although these insights are important, they generally reflect only the perspective of a handful of exporting countries.

Our contribution to the literature is three-fold. First, we provide an overview of world meat production, consumption and trade in the context of FMD. Second, we provide insights into the economics of biosecurity measures and how these activities should be optimally designed. These insights provide important lessons for biosecurity planning in general. Third, we analyse a case study of an FMD-endemic country, Vietnam, which has been trying to achieve FMD-free status. We chose Vietnam for three reasons: (a) Vietnam ranks among the top ten countries in the production, consumption and export of pork (USDA, 2014), thereby having the potential to substantially increase world meat supplies at cheaper prices if it can control TADs; (b) Vietnam is a poor developing country where livestock production is important for household living standards, especially in rural areas, and the development of the livestock sector has large distributional effects in wealth and income due to widespread extensive farming systems already in place (GSO, 2007); and (c) although the Government of Vietnam has been aggressive in their fight against FMD, with millions of dollars spent over more than a decade, FMD is still prevalent throughout large parts of the country. For these reasons, lessons learnt from this case study will shed light on challenges in achieving FMD-free status in endemic countries, which in its turn will be useful for implementing a global FMD control strategy and assist in providing improved food

\footnotetext{
${ }^{1}$ See, for example, Thompson et al (2002); FAO (2002) for economic impacts of actual incursions and Productivity Commission (2002) for that of hypothetical incursions in FMD free countries. A thorough literature review on these economic impacts is provided by Knight-Jones and Rushton (2013).
} 
security.

\section{FMD and the world meat production, consumption and trade}

FMD is highly contagious viral disease affecting cloven-hoofed animals with 7 types and over 80 subtypes (FAO, 2007). Although most infected animals recover, FMD has debilitating effects including weight loss, decrease in milk production, loss in productivity and high mortality rates in young animals (Grubman and Baxt, 2004). The FMD virus rapidly replicates and spreads within the infected animal, and among in-contact susceptible animals, by aerosol and in contact with contaminated animal products, equipment, clothes/shoes, feedstuff or veterinary biologics (GAO, 2002). The FMD virus can stay in recovered animals (the carrier) for 2-5 years and up to 183 days on animate and inanimate objects (GAO, 2002; Grubman and Baxt, 2004; Condy et al, 1985).

Not until the end of the 20th century has FMD been brought under control in developed countries and countries that engage in international livestock trade (Grubman and Baxt, 2004). Yet, FMD remains endemic in most poor developing countries, resulting in low productivity in the husbandry sector (OIE and FAO, 2012) and substantial potential trade losses. To this end, consumers in these FMD affected countries, especially the poor, have less access to animal-source foods which contain high quality protein and micro-nutrients that are essential for normal development and good health (Figure 1).

Being the most important constraint to international trade in animals and animal products, FMD also prevents endemic developing countries from capitalizing on rapid trade liberalisation, with potentially large gains in revenues and income. Indeed, growth in the exports of cloven-hoofed animals and animal products for developing countries has been flat over the past decade (Figure 2). On the other hand, poultry exports seem more resilient to disease outbreaks, increasing exponentially for both developed and developing countries since the early 1990s. However, large gains from trade liberalisation of animals and animal products have clearly accrued, as shown in Figure 2, to developed countries that are free of most TADs.

Having FMD-free status and a strong dependence on international export markets also implies potential massive economic loss once FMD outbreaks occur, regardless of country, as shown in Table 1. When both direct and indirect costs of a FMD epidemic are known, the total cost is in the order of US\$ 243 million to more than US\$ 9 billion, of which indirect costs dominate. The loss to the economy, as a whole, ranges from about $0.01 \%$ to $1.2 \%$ of Gross Domestic Product (GDP). Furthermore, an FMD epidemic often results in a substantial fall in herd sizes due to eradication as the main response strategy, designed to return the system more quickly to FMD-free status. For example, FMD outbreaks in UK, the Republic of Korea (in 2010-2011) and Taiwan resulted in reductions of 10\%, 27\% and 37\%, in the herd sizes of cloven-hoofed animals (Table 1). Although more than a decade has elapsed since the epidemics in the late 1990s and early 2000s, production levels of pork meat in Taiwan and UK have not yet recovered to levels before the epidemics.

Given the potential large damage caused by an FMD incursion, FMD-free countries typically prevent FMD by applying stringent measures at ports of entry in terms of border inspection and quarantine. For example, the USA, UK, Canada, EU and Mexico have focused on main pathways such as the import of live animals and animal products, the handling and disposal of garbage from international carriers, and the screening of international passengers and mail packages (GAO, 2002). No matter how aggressive those preventive measures are, complete protection is unlikely, especially when those measures have not kept up with the increasing volume of international travel and trade. Thus, FMD still occurs in previously FMD-free countries and has caused over US\$ 25 billion over the last 15 years (KnightJones and Rushton, 2013).

Experience has shown that the control and eradication of FMD is impossible without aggressive biosecurity measures and coordination among countries. In fact, harmonisation of control measures, policies and legal frameworks, country-level financial and technical efforts and between-country cooperation in combination with mass vaccination played a decisive role in eliminating FMD in Europe (Grubman and Baxt, 2004). Some regions have been following this successful example. For instance, South America has largely controlled FMD thanks to a regional effort coordinated through the Hemispheric Programme for the Eradication of FMD, coupled with a highly developed 
partnership between the veterinary services and the livestock private sector (Pan American Health Organization, 2014). South East Asian countries have also achieved considerable success in their jointly-run program, the South East Asia Foot and Mouth Disease Programme (SEAFMD), which aims at achieving FMD-free status with vaccination and through biosecurity measures by 2020 (OIE, 2007). In Africa, a corresponding regional effort coordinated via the Southern African Development Community has also proven to be effective despite the challenges caused by the long lasting wildlife maintenance host of the FMD virus (OIE, 2012).

A global FMD control strategy was launched in 2012 with an aim to contribute to improving livelihoods in developing countries and to enhance the trade in animals and animal products. In particular, the strategy emphasises that reducing FMD at source in FMD-endemic countries is 'a shared interest and should be considered a global public good' (OIE and FAO, 2012). Key to the success of the strategy is the progress against FMD in endemic countries, with most of the required funding needed there. Naturally, without any north-south cost-sharing mechanisms specified, achieving this strategy is difficult as epidemic (poor developing) countries can least afford the suggested estimated investment of roughly 0.8 billion US\$ per year. Nevertheless, this investment level is much less than the average loss per year caused by FMD incursions to developed countries over the last 15 years.

\section{The Economics of Biosecurity Measures}

Biosecurity is defined as measures to reduce the risk of disease incursion and the spread of invasive species, ones that potentially affect the environment, human, plant and animal health. Traditional biosecurity measures to prevent these threats have focused on pre-border, border and post-border quarantine measures, local surveillance programs and eradication and containment campaigns where, for the last, a pest or disease has already been detected in the environment.

Biosecurity measures involve essential economic questions. In particular, how much should be spent, or what costs for biosecurity should be incurred to protect animal, plant and human health, as well as the environment? How should resources be allocated across a large number of various threats? Who should pay for this activity? How should expenditures be allocated across the various biosecurity measures? How much should be spent at the border? How much for local surveillance to ensure the early detection of an invasive threat? Should an invasive pathogen be eradicated, contained, or simply ignored and potentially treated at a later date, or not at all?

Although a good deal of research has been conducted on the costs and benefits of specific eradication and containment programs ${ }^{2}$, little has been done on the economics of biosecurity to optimise expenditures both in terms of levels of activity and across different biosecurity measures. Fortunately, the basic principles for the economics of biosecurity are not hard to understand, especially in the case of the livestock sector. The correct approach is characterised for each biosecurity measure below.

\subsection{Border quarantine}

Quarantine measures at the border are designed to reduce or eliminate the probability of an incursion. These measures are usually the focal point of control measures against FMD, especially in developed economies which are FMD-free. There are costs and benefits from this activity. The benefits are avoided losses from a disease entry. With FMD, these can be substantial, especially so because of the resulting economic damages from the loss of market access should an FMD incursion occur. In terms of costs, apart from administrative and border quarantine service expenditures, losses in consumer welfare caused by restricted trade flows are usually seen to be the most significant cost of a quarantine measure.

The key measure for border quarantine is to minimise the sum of the direct costs of a potential disease incursion, the cost of the quarantine program itself and the resulting welfare losses from quarantine restrictions through variation in the potential number of infected livestock that may probabilistically enter a region or a country. The larger the

\footnotetext{
${ }^{2}$ Cook et al (2011), Gohin and Rault (2013), Huaser and McCarthy (2009) and Thompson and Tebbens (2007) are good examples of this kind of work.
} 
expenditure on a quarantine activity is the larger are welfare losses and the cost of the quarantine program. On the other hand, the more severe the quarantine activity the smaller is the risk of a disease incursion and, thus, the smaller are the direct costs of the disease to the affected industry.

In principle, there will be cases where the disease is so devastating that the direct costs of an incursion will require vast expenditures on quarantine services to guarantee that the risk of a disease entry is virtually zero. This is generally the case with FMD. On the other hand, for some diseases, reducing the risk of a disease incursion to zero may imply that the cost of the quarantine measures and the resulting welfare losses more than surpass the (present) value of the direct cost of the disease to the local industry (James and Anderson, 1998). Finding the correct value of the likelihood of a disease entry, and with it the associated expenditure level and optimal quarantine activity thus requires minimising all of the (properly discounted) potential and actual costs associated with managing imported livestock. An illustration of the technique for the optimal control of the entry of Ovine Johne's disease in Western Australia is provided in Kompas and Che (2003).

Local optimal surveillance

Surveillance is the search for 'unknown incursions'. It seeks to achieve 'early detection' of a disease, or detection before the disease is commonly or generally noticed. The cost of surveillance is the money spent to implement the search and the benefit is the value of early detection in terms of avoided losses that would have resulted otherwise. The comparison between the costs and the benefits of a surveillance program depend on how early a search can detect an unknown incursion (or its location) if it is present. An ambitious surveillance program can detect a disease very early, but then the program may be too expensive; while a less expensive program may not detect early enough.

Following Kompas et al. (2004), an optimal surveillance model normally has three main components: (a) a biological component to describe both the growth and density growth of infected herds (in the case of animals); (b) a surveillance expenditure function that maps the cost of surveillance to the spread of the disease and the point of detection; and (c) a measure of production losses before detection occurs, along with disease management costs, and trade and other losses that result during the disease management period, either in terms of disease containment or the time it takes for eradication. The resulting model will evaluate the sum of the three components for each surveillance design and choose the level of surveillance expenditures that minimises the total cost.

\section{Containment and eradication}

Once a disease or a pest is confirmed to be present in an area, there are two basic economic strategies for dealing with it, namely eradication and doing nothing. A combination of these two options, or containment (Cacho et al, 2008), is designed to eradicate a sub-area and keep the disease inside the remaining area, often referred to as a containment zone. Kompas et al. (2013) derived a condition that determines where eradication is more cost-effective than doing nothing: $d+c r \geq c \rho$ where $d, r, c$ and $\rho$ are respectively the annual damage caused by the disease, the annual spread rate of the disease, the eradication cost and the discount rate. The right hand side of the condition represents the benefit of eradication, i.e., the avoided losses if eradication measures are taken immediately. Otherwise, delaying eradication will incur a damage plus the cost of eradicating the new infection, but can save the interest paid on the eradication cost. For FMD, annual damages are typically very large and easily rationalize the need for containment and eradication strategies, such as culling and vaccination.

\section{Vietnam}

In this section, we first provide some background on Vietnam in terms of the importance of the livestock sector and the adverse effects caused by the TADs it has experienced. We then discuss the FMD situation in Vietnam, its biosecurity issues and its strategy to control and eradicate FMD. Finally, we present the key challenges faced by Vietnam in order to achieve an FMD-free status. 
Vietnam is a developing country that has achieved remarkable progress in its transition from a command to a market economy, starting in 1986. During the period 1990-2010, the average GDP growth rate was 7\%; GDP per capita more than tripled; and the proportion of poor people, most of them in rural areas, fell sharply from $58 \%$ to under $10 \%$ (WB, 2012; GSO, 2011, 2009, 2000). As income has increased, there has been a shift in the Vietnamese diet. In particular, staple foods such as rice are now less dominant (Ha et al, 2015), while meat and dairy products have become more important (Figure 3). Among meat products, consumption of pork has increased dramatically, with per capita consumption more than tripling between 1990 and 2010 (Figure 4). To keep up with this ever-increasing demand, meat production per capita has grown exponentially, especially since the early 1990s, with pork playing a leading role (Figure 4). As of 2010, Vietnam is among the world's top ten largest pork-producing countries (USDA, 2014).

A key challenge for Vietnam's livestock sector is the prevalence of infectious animal diseases. This prevalence results in low meat production and creates barriers to trade for Vietnam's meat and meat products. Productivity in Vietnam is far below that in OECD countries in terms of cattle, pig and poultry meat and milk output per animal per year, with animal diseases being one of the contributing factors (RUDEC, 2008; Knips, 2004). In terms of trade, Vietnam's

livestock sector struggles to access markets overseas mostly due to TADs (Nguyen and Xuan, 2014). Meanwhile, with integration and increasing domestic living standards, Vietnam's livestock suppliers are losing market share in the domestic market for not being competitive in price and quality, and are often seen as not trustworthy from the customers' point of view in terms of compliance with international food safety standards (Thanh Nguyen, 2014). Competition has become fierce in the domestic market especially since Vietnam's WTO accession in 2007, which brought about lower tariffs for imported agricultural products and less protection for domestic producers (Ha Yen, 2014). Thus, meat imports have increased rapidly since 2007 (

Figure 5).

FMD and biosecurity control measures

FMD has been in existence in Vietnam for more than a century but, until recently, remained largely local with virus type O Manisa identified as the main strain (Van et al, 2008). Since the early 1990s, FMD has substantially increased in the frequency and size of outbreaks due to increased cross-border trade (MARD, 2001). In fact, new virus types including A Malaysia 97 and Asia 1 Shirmia were brought into Vietnam in 2004 and 2005 from Cambodia and China, respectively, due to cross-border (mostly illegal) trade of cattle (Van et al, 2008). Dramatically increasing trade makes FMD control more complicated and costly. This is especially the case with a long border and limited border quarantine measures in place in Vietnam.

Given the importance of livestock in both consumption and production, the Government of Vietnam has been active in its fight against FMD. At the global level, Vietnam has been a member of the World Organization for Animal Health (OIE) since 1991, shortly after the launch of its landmark reforms. At the regional level, it is one of the core founding members of the SEAFMD campaign, launched in 1997, with the aim of achieving freedom from FMD through vaccination in South-East Asia by 2020 (OIE, 2007). At the country level, Vietnam is in a self-assessed stage 3 in the 5stage FMD progressive control pathway (PCP) toward FMD-free status, as suggested by the FAO (Nguyen, 2012). That is, Vietnam is in the stage of focusing on the progressive elimination of the FMD virus, and new trade-related options such as compartmentalisations, local quarantine zones and commodity-based approaches to trade are becoming feasible (OIE and FAO, 2012).

Vietnam has progressed in the PCP towards FMD-free status by first implementing a national framework plan and then a national program. The former, called the National Framework Plan for FMD control for the period 2001-2004, helped establish a sound legal framework on FMD prevention and protection, the training of veterinary staff, and measures to increase public awareness (MARD, 2001). All of these activities underpinned the development and implementation of the later National Program on FMD control and eradication, which was launched in 2006 and designed in phases. Each 5-year phase of this program costs Vietnam about US\$ 31-33 million, most of which is spent on vaccination as the principal containment and eradication biosecurity measure (MARD, 2010; Kompas et al, 2011; MARD, 2011). 
Constrained in budget, the program covers mostly the vaccination of buffaloes and cattle. Indeed, about $43 \%$ of the total of some 9 million buffalos and cattle in Vietnam are vaccinated under this program (Kompas et al, 2011). The corresponding proportion is about 3\% for a total of some 27 million pigs (Kompas et al, 2011). The main reason for this choice is that the cost effectiveness is higher for the vaccination of buffaloes and cattle, as opposed to pigs, due to their longer lifespan (12-24 months versus 6-8 months) and higher market value. Furthermore, in most parts of rural Vietnam, buffaloes and cattle are raised to provide draft power, thereby staying with farmers for 10 to 15 years. Costbenefit measures of this biosecurity activity are scarce. A recent study shows the benefits in terms of four main (albeit limited) components: (a) the value of culled and/or dead cows and buffaloes; (b) the value and weight loss of cows and buffaloes due to being FMD infected; (c) any milk loss due to infected cows; and (d) any other expenses associated with an outbreak. Even with the most conservative measures and methodology in place, the gains from the program are substantial at a net present value (NPV) of US\$ 1.22 billion. This is equivalent to US\$ 82 million every year, in current dollars, from 2006 to 2033, the course of the study, with a benefit-cost ratio of 5.26 (Kompas et al, 2011).

Apart from the national program, two other sources also fund vaccination against the FMD virus for cloven-hoofed animals. The first is the national emergency fund, which provides vaccines in case of natural hazards and shortage of vaccines due to outbreaks, etc. (MARD, 2011). The second is from private farms, typically those with 50 or more heads (RUDEC, 2008).

Under the national program, Vietnam normally implements progressive zoning in its vaccination against the FMD virus. Three zones including a control zone, a buffer zone and a low risk zone are established based on epidemiological data, recommendations of the World Organisation for Animal Health (OIE)'s experts, geographical conditions, livestock farming practices and other socio-economic conditions (MARD, 2005). In the first two zones, 100\% of buffaloes and cattle are vaccinated with full funding from the central government for the control zone, while funding is split between the central and provincial governments for the buffer zone. In the low risk zone, on the other hand, vaccination is only provided in areas with outbreaks over the past five years (MARD, 2011).

Of importance to the success of the program are technical measures. They include the choice of suitable vaccines in combination with effective zoning, local disease surveillance and post-vaccination monitoring, slaughter and movement control of animals and animal products, along with cleaning and disinfection (MARD, 2011). Along the lines with these technical measures are activities for strengthening capacity, increasing awareness and communication, and international collaboration.

The first phase 2006-2010 of the program was implemented with good results (MARD, 2011). FMD was been more or less under control in many provinces and outbreaks had been reduced in both frequency and scope (Figure 6), contributing to the development of the livestock sector in many areas. However, Figure 6 also reveals the persistent nature of the disease for the period 2007-2010. In addition, the magnitude of the epidemic in 2011 presents a substantial setback to the program's progress, all reflecting the ongoing challenges in the fight against FMD.

Challenges in controlling and eradicating FMD in developing countries

Vietnam is faced with many challenges in its fight against FMD. Most are typical for a developing country. First, the predominance of extensive livestock systems imposes pressure on FMD prevention and control. Every one out of two rural households in Vietnam is involved in raising pigs, and 20\% and $11 \%$ rural households are involved in raising buffaloes and cattle, respectively, albeit most with less than 10 heads per household (GSO, 2007). These small scale and highly decentralised systems seriously affect the actual rate of vaccination. For instance, in spite of the sufficient provision of vaccines in the first phase of the program, rates of vaccination were less than 50\% (against the expected $100 \%$ rate) in some mountainous and remote areas where free-range livestock is not uncommon (MARD, 2010). Smallscale production is also associated with little local knowledge about livestock husbandry. Some households, for example, refused to have their animals vaccinated (although at no cost to them) for fear that it would affect their weight (DAH, 2011).

Second, weak institutions cannot keep up with fast socio-economic changes and the growth of the livestock sector. 
For example, reforms and increasing integration into the world economy bring about arbitrage opportunities within and between countries, which induce livestock movement. This movement is often difficult to track or monitor. Furthermore, widespread illegal imports of live cattle occur in Vietnam across a long border of roughly $3000 \mathrm{~km}$ with Laos and Cambodia, in difficult topographical conditions, with thousands of entry points not monitored by a quarantine facility. Imported animals are then transported inland. This adds considerably to the difficulty of controlling FMD.

Third, against this backdrop, border control, border quarantine measures and the monitoring of internal livestock movement lags well behind what is needed, making the control of FMD very difficult. Weak institutions, coupled with the lack of capacity of staff at local levels also result in poor management of outbreaks due to the lack of appropriate coordination and the presence of overlapping responsibilities among authorities at different levels (DAH, 2011). For these reasons, animals in areas with outbreaks are not always treated as regulations require and animal movements are not strictly controlled. Weak capacity of veterinary staff at local levels, with little training and poor wages, also often result in excessively late reports of outbreaks (for example, up to three months late) or at times no reports of outbreaks at all, with animals allowed to move freely (DAH, 2011). Regrettably, some local vets are even thought to hide outbreaks in order to benefit directly from treating a larger number of infected animals (DAH, 2011).

Finally, there is simply widespread lack of awareness of and compliance with regulations on disease prevention and protection, as well as food safety and hygiene among people and authorities at different levels (MARD, 2011). This clearly results in lower efficacy of vaccination programs and lower effectiveness of FMD prevention and control measures.

\section{Concluding Remarks}

Food security requires continued and enhanced livestock production. Disease and animal disease transmission limit the ability of the livestock sector to meet growing food security needs. FMD, in particular, results in a loss of productivity and herd size, and severely constrains trade opportunities. Without trade access, it is more difficult for local livestock industries to develop and increase production. Industry development also generates resources to help fund quarantine and local surveillance activities. At the moment, many developing countries are caught in a 'trap' of having to deal with significant animal disease issues, which limit the ability of the livestock sector to grow and develop both the infrastructure and the sufficient means to implement a full range of biosecuity measures. This trap is underscored by the experience in Vietnam.

What is also clearly seen from the Vietnamese experience is the need for regional and, for that matter, global responses to FMD. This response is in place (OIE and FAO, 2012), but still a good distance away from being realized. In this sense, there can also be no doubt that biosecurity and food security go hand-in-hand. In Vietnam, much is being done to control FMD but extensive vaccination measures will not be enough. Like many FMD-endemic countries, livestock movement and control is not adequately monitored in Vietnam, either at the border or within the country. Regional solutions will help control borders, but local expertise in biosecurity measures needs to improve radically. The control of livestock movements, local surveillance for early detection, border quarantine, enforcement of buffer zones and local quarantine areas and enhanced veterinary skills and facilities all need to be part of the answer. The payoff from control is profound, and if these sorts of activities can be coordinated and resourced both regionally and globally, we may well contemplate a future world free of FMD. 
Figure 1: FMD status (2014) versus meat production and consumption (2009-2011)
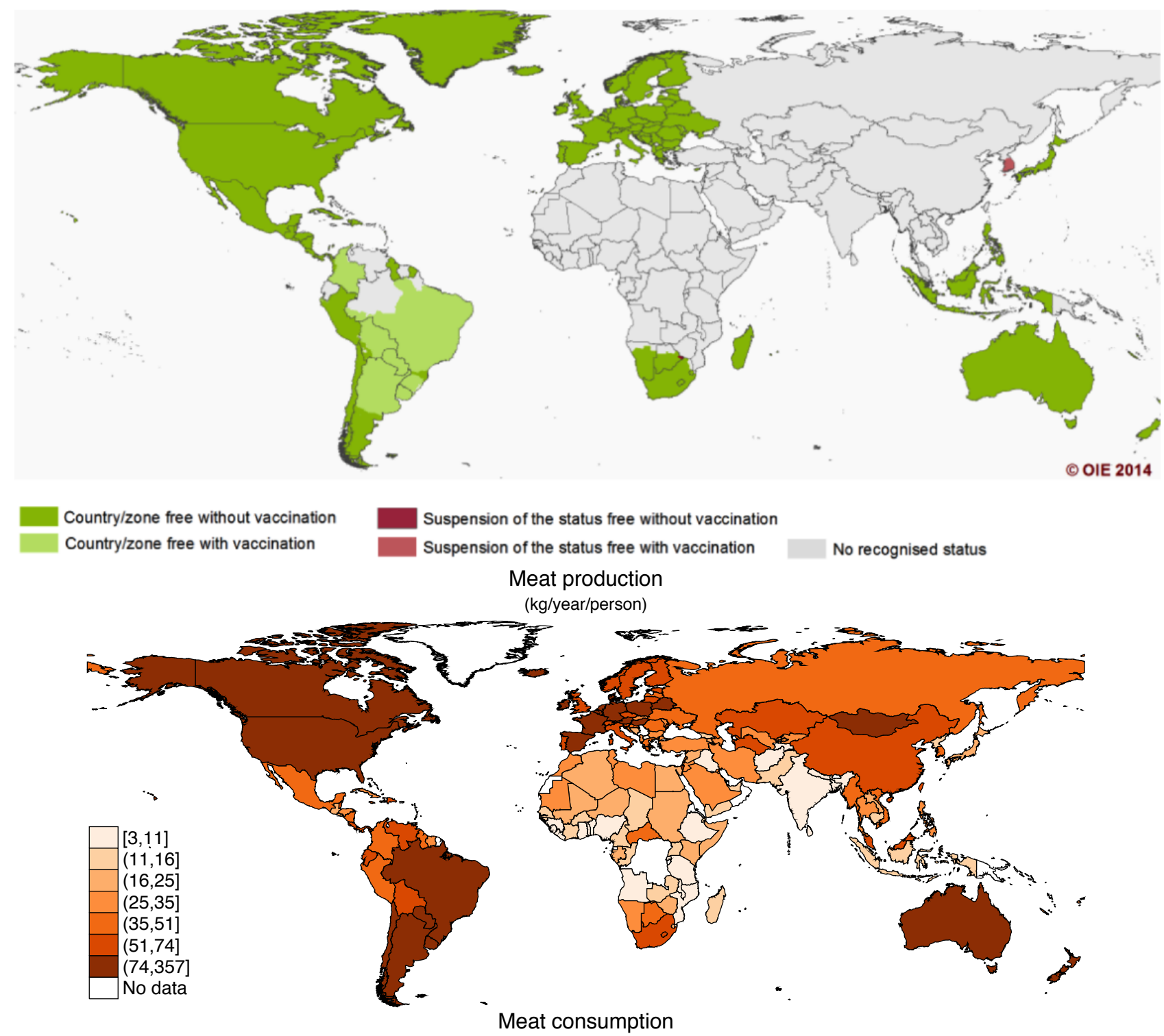
(kg/year/person)

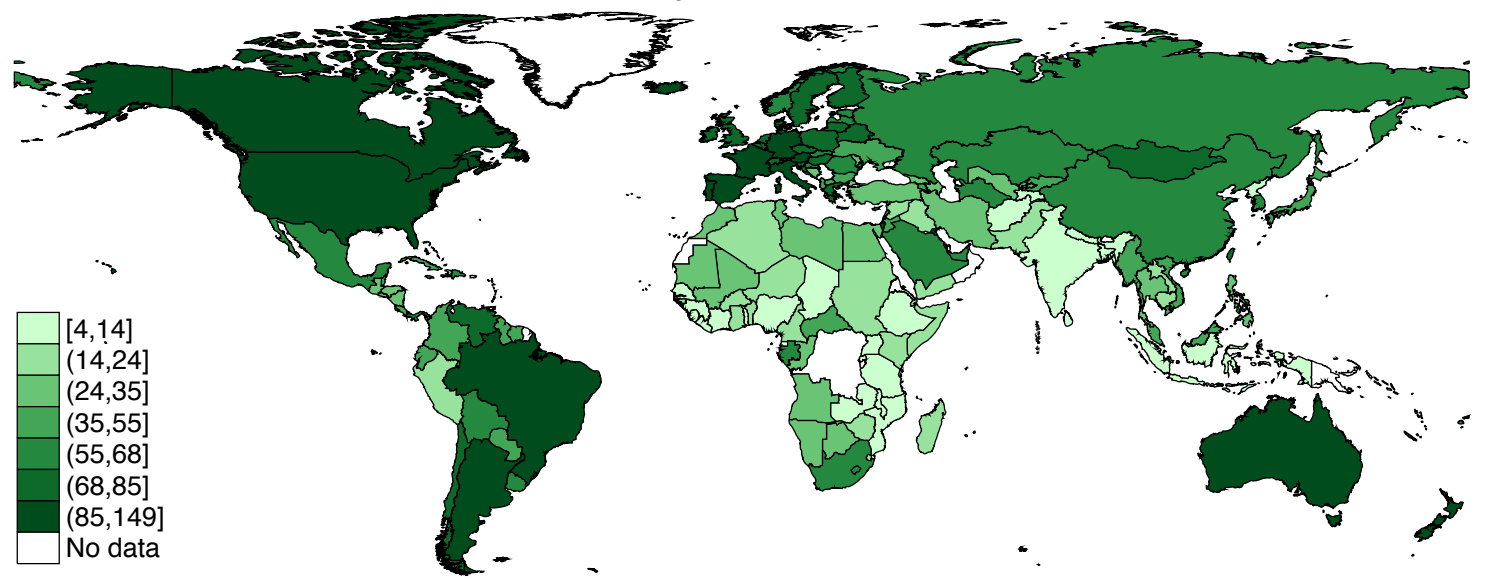

Data on official FMD status is from OIE (2014) and meat production and consumption (kg/person/year) is the average of years 2009-2011 (calculated using data from FAO (2014)) 
Figure 2: Livestock exports

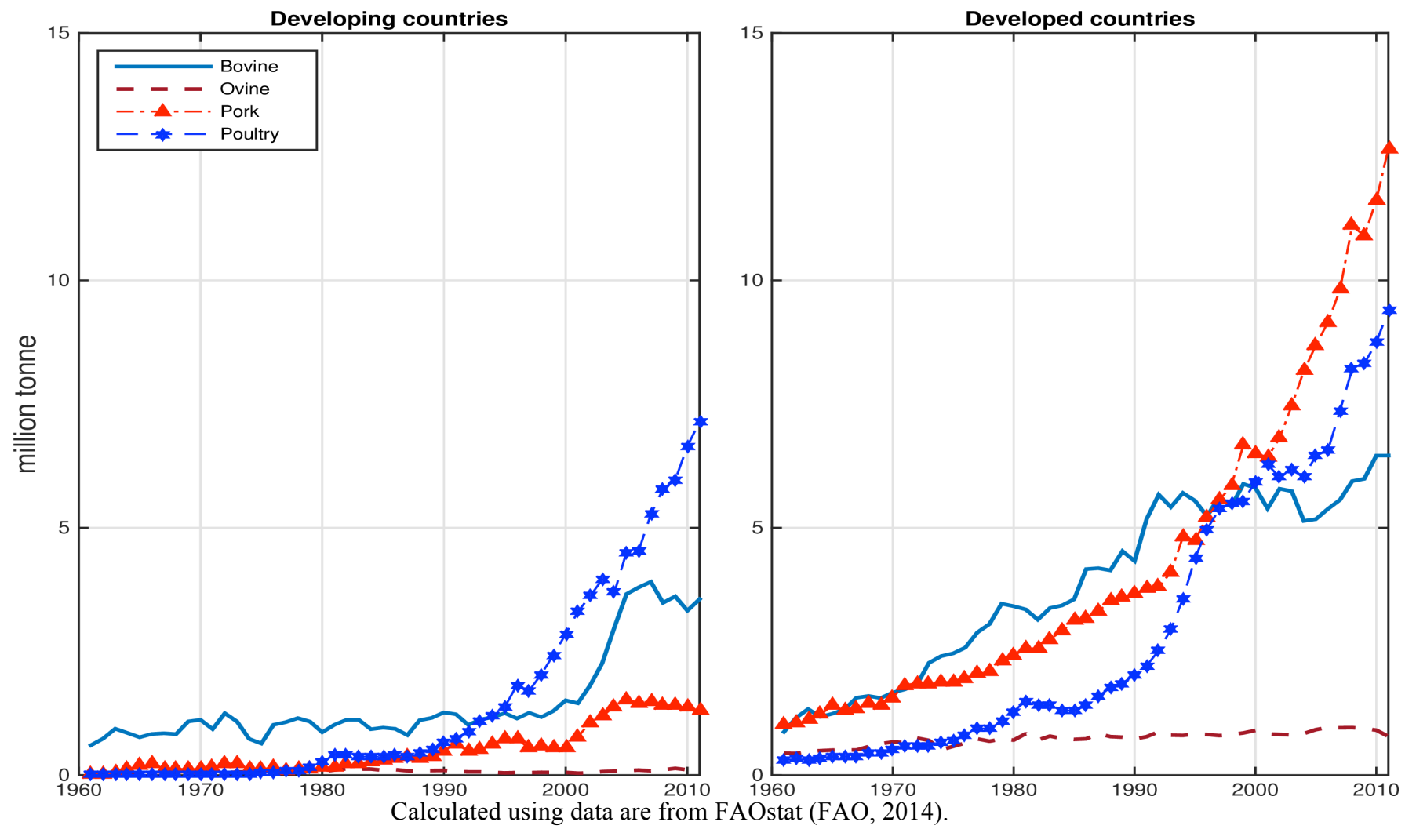

Figure 3: Food balance: Vietnam versus developing and developed country averages

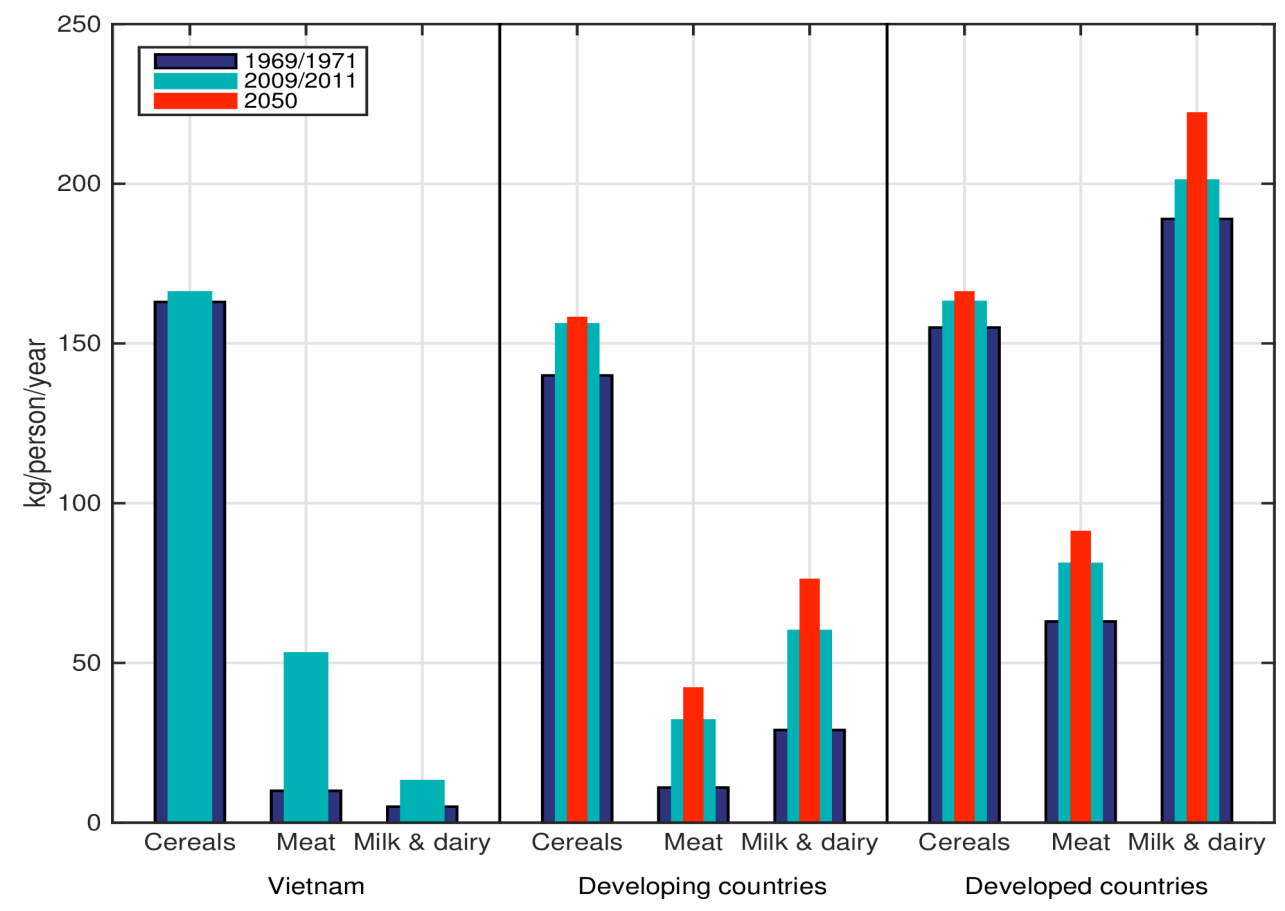

Estimates for 1969/1971 and 2009/2011 are produced using data from FAOstat (FAO, 2014). Projections for 2050 are from Alexandratos and Bruinsma (2012) and not available for Vietnam. 
Figure 4: Meat production and consumption in Vietnam

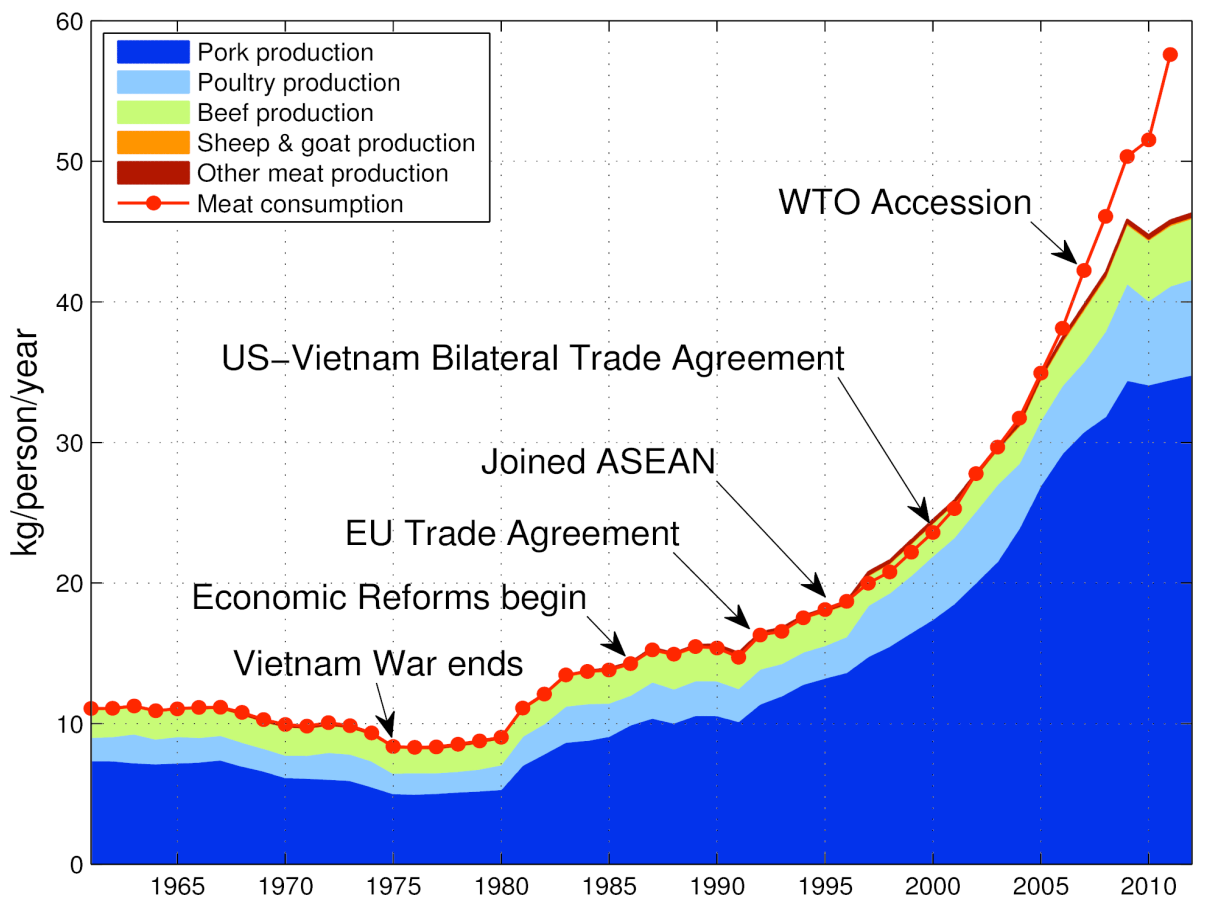

Calculated using data from FAOstat (FAO, 2014).

Figure 5: Meat imports and exports in Vietnam

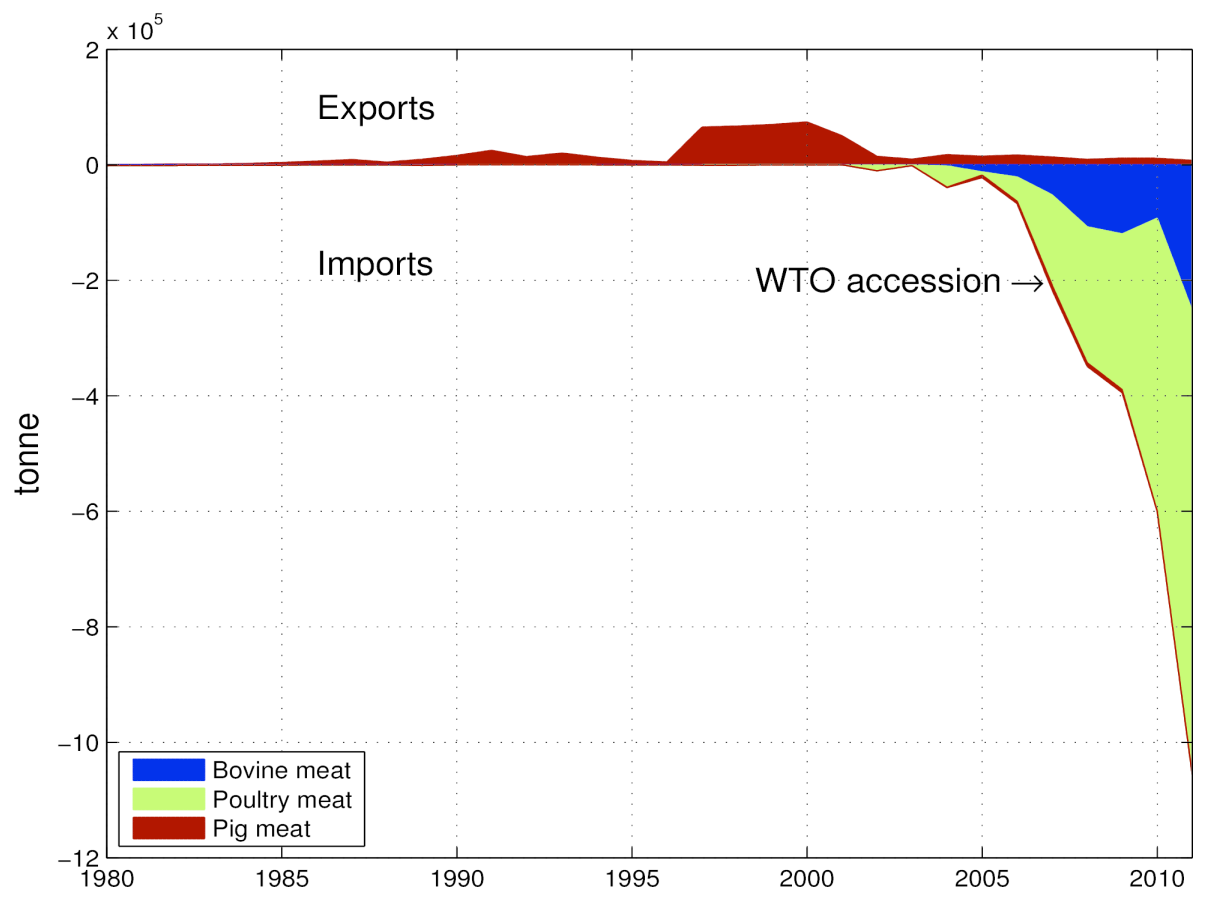

Calculated using data from FAOstat (FAO, 2014). 
Figure 6: FMD situation in Vietnam, 2006-2011
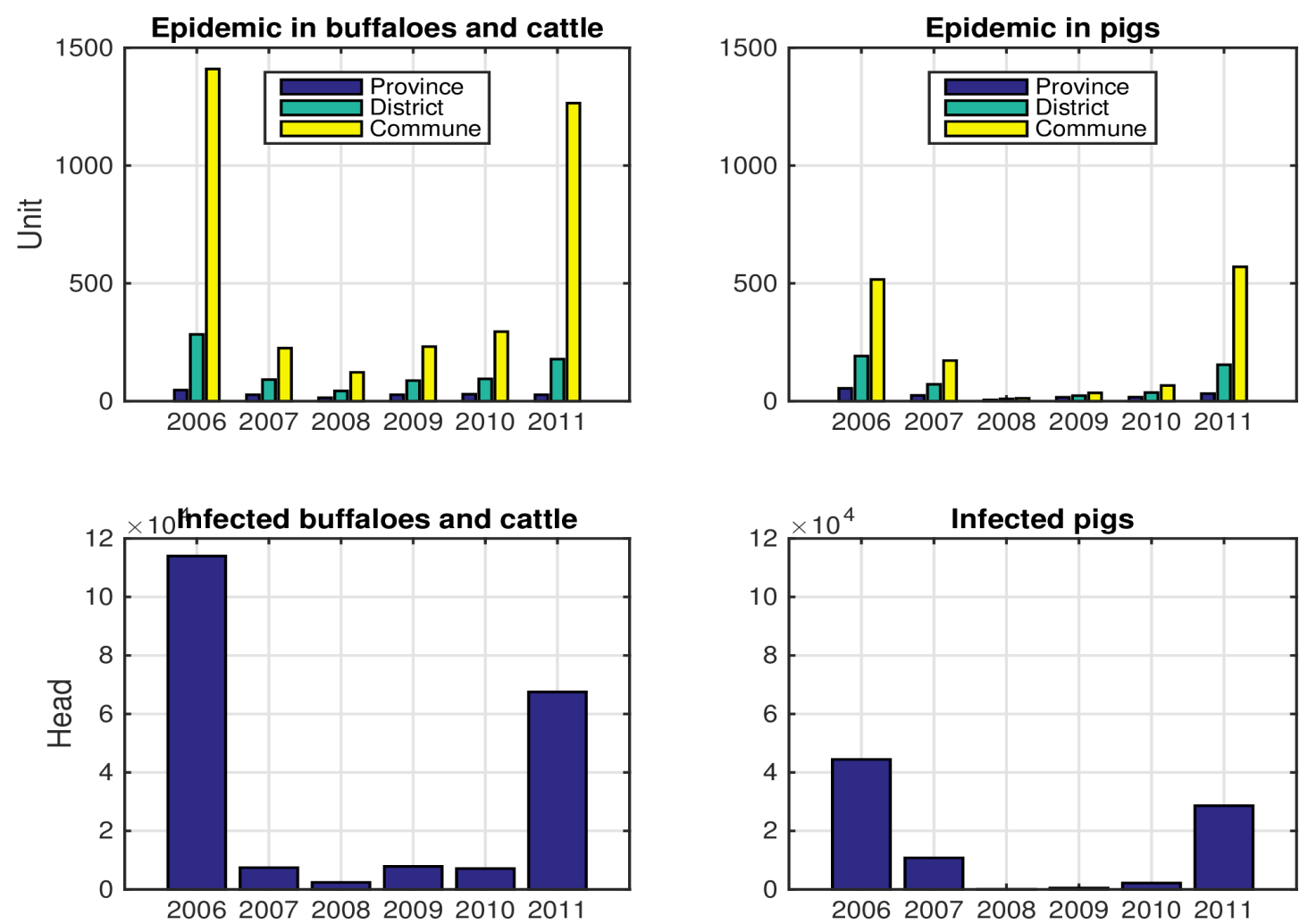

Data from MARD (2011) and DAH (2011). 
Table 1: Costs of some FMD epidemics in FMD previously free countries

\begin{tabular}{|c|c|c|c|c|c|c|c|c|c|}
\hline & \multirow{2}{*}{$\begin{array}{c}\text { Taiwan }^{(\mathrm{c})} \\
1997\end{array}$} & \multicolumn{2}{|c|}{ Uruguay $^{(\mathrm{d})}$} & \multicolumn{2}{|c|}{ Republic of Korea } & \multicolumn{2}{|c|}{ Japan } & \multirow{2}{*}{$\begin{array}{l}\text { Nether- } \\
\text { lands }^{(\mathrm{g})} \\
2001\end{array}$} & \multirow{2}{*}{$\begin{array}{l}\mathrm{UK}^{(\mathrm{c})} \\
2001\end{array}$} \\
\hline & & 2000 & 2001 & $2000^{(\mathrm{c})}$ & $2010-11^{(\mathrm{e})}$ & $2000^{(\mathrm{c})}$ & $2010^{(\mathrm{f})}$ & & \\
\hline Trade linkage $\mathrm{e}^{(\mathrm{a})}$ & $26 \%$ & $39 \%$ & $45 \%$ & $9 \%$ & $1 \%$ & $70 \%$ & $91 \%$ & $58 \%$ & $16 \%$ \\
\hline $\begin{array}{l}\text { Direct cost } \\
\text { (current US\$ } \\
\text { mil) }\end{array}$ & 254 & na & 13.6 & 433 & 2700 & 15 & 550 & na & 3558 \\
\hline $\begin{array}{l}\text { Indirect cost } \\
\text { (current US\$ } \\
\text { mil) }\end{array}$ & 6363 & na & 230 & na & na & na & na & na & 5646 \\
\hline $\begin{array}{l}\text { Total cost } \\
\text { (current US\$ } \\
\text { mil) }\end{array}$ & 6617 & na & 243.6 & 433 & 2700 & 15 & 550 & 881.3 & 9204 \\
\hline $\begin{array}{l}\text { Total cost } \\
\text { (percentage of }^{(a)} \\
\text { GDP) }\end{array}$ & $-0.64 \%$ & na & $-1.2 \%$ & $-0.08 \%$ & $-0.25 \%$ & $-0.00032 \%$ & $-0.01 \%$ & $-0.22 \%$ & $-0.2 \%$ \\
\hline $\begin{array}{l}\text { Duration } \\
\text { (months) }\end{array}$ & 4.5 & 4 & 4 & 1 & 5 & 1 & 3 & 2 & 7.5 \\
\hline Control methods & $\mathrm{SO}+\mathrm{Vac}$ & SO & $\mathrm{SO}+\mathrm{Vac}$ & $\mathrm{SO}+\mathrm{Vac}$ & $\mathrm{SO}+\mathrm{Vac}$ & $\mathrm{SO}$ & $\mathrm{SO}+\mathrm{Vac}$ & $\mathrm{SO}+\mathrm{Vac}$ & $\mathrm{SO}$ \\
\hline $\begin{array}{l}\text { Slaughtered } \\
\text { animals (head) }\end{array}$ & $4.03 \mathrm{mil}$ & 19,552 & 6,937 & 2216 & $3.48 \mathrm{mil}$ & 740 & 290,000 & 260,000 & $6.24 \mathrm{mil}$ \\
\hline $\begin{array}{l}\text { Slaughtered } \\
\text { animals } \\
\text { (percentage of } \\
\text { the cloven- } \\
\text { hoofed animal } \\
\text { herd) }\end{array}$ & $36.7 \%$ & $0.076 \%$ & $0.028 \%$ & $0.020 \%$ & $26.9 \%$ & $0.51 \%$ & $2.02 \%$ & $1.39 \%$ & $10.4 \%$ \\
\hline
\end{tabular}

(a) Trade linkage is approximated by a percentage of export volume in total production of meat of clovenhoofed animals. Data on export volume, production and herd size are from FAOstat (FAO, 2014). Data on GDP are from World Bank Indicator (World Bank, 2014).

(b) SO: stamping out; Vac: Vaccination.

${ }^{\text {(c) }}$ FAO (2002)

(d) Sutmoller and Olascoaga (2002)

(e) The number of slaughtered animals, control methods and duration of the epidemic is from Park et al (2013) while economic loss is from various media sources such as (CNN, 2014; Food Safety News, 2014)

${ }^{(\mathrm{f})}$ Muroga et al (2012)

(g) The number of slaughtered animals, control methods and duration of the epidemic is from Bouma et al (2003) while economic loss is from Knight-Jones and Rushton (2013), which is converted into current USD using exchange rates from International Financial Statistics (IMF, 2014) 


\section{References}

Alexandratos N, Bruinsma J (2012) World agriculture towards 2030/2050: the 2012 revision. ESA Working paper No. 12-03. FAO: Rome.

Bouma A, Elbers A, Dekker A, De Koeijer A, Bartels C, Vellema P, Van der Wal P, Van Rooij E, Pluimers F, De Jong M (2003) The foot-and-mouth disease epidemic in the Netherlands in 2001. Preventive Veterinary Medicine 57(3): $155-166$.

Cacho OJ, Wise RM, Hester SM, Sinden J (2008) Bioeconomic modeling for control of weeds in natural environments. Ecological Economics 65(3): 559-568.

Cacho, OJ, Hester, SM. and Spring, D. (2007), 'Applying search theory to determine the feasibility of eradicating an invasive population in natural environments', Australian Journal of Agricultural and Resource Economics, 51: 42543.

CNN (2014) Foot and mouth disease fast facts. Available at http://edition.cnn.com/2013/09/02/health/foot-andmouth-disease-fast-facts/ [Accessed: 14 November 2014]

Condy J, Hedger R, Hamblin C, Barnett I (1985) The duration of the foot-and-mouth disease virus carrier state in African buffalo (i) in the individual animal and (ii) in a free-living herd. Comparative Immunology, Microbiology and Infectious Diseases 8(3): 259-265.

Cook D, Carrasco L, Paini D and Fraser R. (2011), 'Estimating the social welfare effects of New Zealand apple imports', Australian Journal of Agricultural and Resource Economics, 55 (4): 599-620.

DAH (2011) Report on prevention and protection of livestock and poultry diseases in 2011 and plan for 2012 (in Vietnamese: "Bao cao tong ket cong tac phong chong benh gia suc gia cam nam 2011 and phuong huong nam 2012”. Hanoi: Department of Animal Health, Epidemiology Division.

FAO (2002) Committee on commodity problems. intergovernmental group on meat and dairy products - animal diseases: Implications for international meat trade. 19th session, 27-29 August 2002. Available at http://www.fao.org/docrep/MEETING/004/y6975e.htm [Accessed: 7 November 2014]

FAO (2007) Foot-and-mouth disease: Situation worldwide and major epodemiological events in 2005-2006. Focus on... Issue No 1. Available at http://www.fao.org/3/a-ai339e.pdf [Accessed: 7 November 2014].

FAO (2013) World livestock 2013: changing disease landscapes. Food and Agriculture Organization of the United Nations: Rome, Italy.

FAO (2014) Fao statistics. Food and Agriculture Organization of the United Nations, Statistics Division: Rome, Italy

Food Safety News (2014) Foot \& Mouth May Taint South Korean Bottled Water. Available at http://www.foodsafetynews.com/2011/05/south-korea-foot-mouth-disease-threat- to-bottled-water/\#.VGK98UsVqf0 [Accessed: 14 November 2014]

GAO (2002) Foot and mouth disease: to protect US livestock, USDA must remain vigilant and resolve outstanding issues. United States General Accounting Office. Report to the Honorable Tom Daschle, US Senate.

Gohin A. and Rault A. (2013), 'Assessing the economic costs of a foot and mouth disease outbreak on Brittany: A dynamic computable general equilibrium analysis', Food policy, 39: 97-107.

Grubman MJ, Baxt B (2004) Foot-and-mouth disease. Clinical microbiology reviews 17(2): 465-493.

GSO (2000) Statistical Yearbook of Vietnam 1999. Statistical publishing house: Hanoi.

GSO (2007) Results of the 2006 rural, agricultural and fishery census. Statistical publishing house: Hanoi.

GSO (2009) Statistical Yearbook of Vietnam 2008. Statistical publishing house: Hanoi.

GSO (2011) Statistical Yearbook of Vietnam 2011. Statistical publishing house: Hanoi.

Ha PV, Nguyen HTM, Kompas T, Che TN, Trinh B (2015) Rice Production, Trade and the Poor: Regional Effects of Rice Export Policy on Households in Vietnam. Journal of Agricultural Economics, 66(2): 1-28.

Ha Yen (2014) Imported meat, 3-year plan to seize Vietnamese market. In Vietnamese "Thit nhap ngoai, ke hoach 3 nam chiem thi truong Viet". Vietnam net. Available at http://vietnamnet.vn/vn/kinh-te/166688/thit-ngoai-nhap-kehoach-3-nam-chiem-thi- truong-viet.html [Accessed: 5 December 2014]

Hauser C. and McCarthy M. (2009), 'Streamlining search and destroy: cost-effective surveillance for invasive species management', Ecology Letters, 12 (7): 683-92. 
IMF (2014) International Financial Statistics. Available from http://elibrary- data.imf.org/DataExplorer.aspx [Accessed: 18 September, 2014]

James S, Anderson K (1998) On the need for more economic assessment of quarantine policies. Australian Journal of Agricultural and Resource Economics 42(4): 425-444.

Knight-Jones T, Rushton J (2013) The economic impacts of foot and mouth disease-what are they, how big are they and where do they occur? Preventive Veterinary Medicine 112(3): 161-173.

Knips V (2004) Review of the livestock sector in the Mekong countries. Livestock sector report Cambodia, Lao PDR, Thailand and Vietnam. Food and Agriculture Organization of the United Nations

Kompas T, Che TN (2003) A practical border quarantine measure for imported livestock. International and Development Economics Working Papers (03-1), Crawford School of Economics and Government, Australian National University, Canberra.

Kompas T, Che TN, Cao L, Klijn N (2004) Optimal surveillance measures against an imported pest or disease: An application to papua fruit fly in Australia. Australian Bureau of Agricultural and Resource Economics, Commonwealth of Australia, Canberra.

Kompas T, Nguyen HTM, Ky VD (2011) Protecting the rural poor: evaluating containment measures against foot-andmouth disease in vietnam. In: Nguyen T (ed) Poverty, Vulnerability and Social Protection in Vietnam: Selected Issues, Hanoi: The Gioi Publishers, 101-165.

Kompas T, Chu L, Che T, Nguyen H, White K (2013) Optimal Surveillance Measures Against Exotic Weeds: An Application to Hawkweed in Australia. Australian Centre for Biosecurity and Environmental Economics, Australian National University, Canberra.

Leforban Y (1999) Prevention measures against foot-and-mouth disease in Europe in recent years. Vaccine 17(13): $1755-1759$.

MARD (2001) Framework plan: foot-and-mouth disease prevention and protection in Vietnam in 2001-2004 (In Vietnamese: "Ke hoach khung: cong tac phong chong benh lo mom long mong tai Vietnam giai doan 2001-2004". Hanoi: Ministry of Agriculture and Rural Development.

MARD (2005) The national program on foot-and-mouth disease control and eradication for the period 2006 - 2010 (in Vietnamese: "Chuong trinh quoc gia khong che benh lo mom long mong giai doan 2006 - 2010". Hanoi: Ministry of Agriculture and Rural Development.

MARD (2010) Report on implementation of the national program on foot-and-mouth disease control and eradication, period 2006 - 2010, proposal for period 2011 - 2015 (in Vietnamese: "Bao cao ket qua thuc hien chuong trinh quoc gia khong che va thanh toan benh LMLM giai doan 2006 - 2010, de xuat giai doan 2011 - 2015". Hanoi: Ministry of Agriculture and Rural Development.

MARD (2011) The national program on foot-and-mouth disease control and eradication, phase II: 2011 - 2015 (in Vietnamese: "Chuong trinh quoc gia khong che benh lo mom long mong giai doan II: 2011 - 2015". Hanoi: Ministry of Agriculture and Rural Development.

Morgan N, Prakash A (2006) International livestock markets and the impact of animal disease. Rev Sci Tech 25(2): 517-528.

Muroga N, Hayama Y, Yamamoto T, Kurogi A, Tsuda T, Tsutsui T (2012) The 2010 foot-and-mouth disease epidemic in japan. The Journal of veterinary medical science/the Japanese Society of Veterinary Science 74(4): 399-404.

Nguyen P, Xuan T (2014) Not easy to export pork to Russia. In Vietnamese "Khong de xuat khau lon sang Nga". Dan Viet newspaper. Available at http://danviet.vn/kinh-te-nong-nghiep/khong-de-xuat-khau-thit-lon-sang-nga496937.html [Accessed: 5 December 2014]

Nguyen TT (2012) Review of works related to FMD control in Vietnam relevant to FMD PCP. Presentation in National Consultation Workshop on FMD PCP in Viet Nam, 20-21 August 2012, Ho Chi Minh City, Viet Nam.

OIE (2007) SEAFMD 2020 A roadmap for foot and mouth disease freedom with vaccination by 2020 in South East Asia. OIE: Thailand.

OIE (2012) Report on FMD in Africa. 7th meeting of the GF-TADs regional steering committee for Africa (SC7), Nairobi, 16-17 July. Available at http://www.fao.org/docs/eims/upload/304034/an398e.pdf [Accessed: 14 November 2014]

OIE (2014) Foot and mouth disease. Available at http://www.oie.int/en/animal-health-in- the-world/official-diseasestatus/fmd/en-fmd-carte/ [Accessed: 14 November 2014] 
OIE and FAO (2012) The global foot and moth disease control strategy: strengthening animal health systems through improved control of major diseases. Available at http://www.oie.int/doc/ged/D11886.PDF [Accessed 7 November 2014]

Pan American Health Organization (2014) Hemispheric program for the eradication of foot- and-mouth disease: Action plan 2011-2020. Pan American Health Organization: Brazil.

Park JH, Lee KN, Ko YJ, Kim SM, Lee HS, Shin YK, Sohn HJ, Park JY, Yeh JY, Lee YH, et al (2013) Control of footand-mouth disease during 2010-2011 epidemic, South Korea. Emerging infectious diseases 19(4): 655.

Productivity Commission (2002) Impact of a foot and mouth disease outbreak on Australia. Research Report. Canberra: AusInfo. Available at http://www.ava.com.au/node/1649. [Accessed: 5 December 2014]

RUDEC (2008) Survey report. Survey on structure and changes in farming and sales systems in livestock sector. In Vietnamese "Bao cao dieu tra. Dieu tra ve co cau va bien dong phuong thuc san xuat, va tieu thu san pham trong chan nuoi”. Rural development centre, Institute of Policy and Strategy for Agriculture and Rural Development: Hanoi.

Sutmoller P, Olascoaga RC (2002) The successful control and eradication of Foot and Mouth Disease epidemics in South America in 2001. Evidence for the Temporary Committee on Foot and Mouth Disease of the European Parlement, Meeting 2 September 2002, Strasbourg.

Thanh Nguyen (2014) Struggle with restructuring the livestock sector. In Vietnamese "Loay hoay tai co cau nganh chan nuoi". Hai quan newspaper online. Available at http:/www.baohaiquan.vn/pages/loay-hoay-tai-co-cau-nganh-channuoi.aspx [Accessed: 5 December 2014]

Thompson D, Muriel P, Russell D, Osborne P, Bromley A, Rowland M, Creigh-Tyte S, Brown C (2002) Economic costs of the foot and mouth disease outbreak in the United Kingdom in 2001. Revue scientifique et technique Office international des epizooties 21(3): 675-685.

Thompson K. and Tebbens R. (2007), 'Eradication versus control for poliomyelitis: an economic analysis', Lancet, 369: 1363-71.

USDA (2014) Livestock and poultry: World markets and trade. Issued in October 2014. Available at http://www.fas.usda.gov/data [Accessed: 21 November 2014]

Van DK, Hoang VN, Nguyen VL, Pham QM, Do HD, Nguyen NT, Ngo TL (2008) Epidemilogical map of foot-andmouth disease in 2006-2007. Research report. Animal Health Department, Ministry of Agriculture and Rural Development of Vietnam.

WB (2012) Well begun, not yet done: Vietnam's remarkable progress on poverty reduction and the emerging challenges. World Bank report No. 70798-VN.

World Bank (2014) World Development Indicator. Available from http://data.worldbank.org/indicator [Accessed: 18 September, 2014] 


\section{University Library}

\section{- M M I N E R VA A gateway to Melbourne's research publications}

Minerva Access is the Institutional Repository of The University of Melbourne

Author/s:

Kompas, T;Hoa, TMN;Pham, VH

Title:

Food and biosecurity: livestock production and towards a world free of foot-and-mouth disease

Date:

2015-04-01

Citation:

Kompas, T., Hoa, T. M. N. \& Pham, V. H. (2015). Food and biosecurity: livestock production and towards a world free of foot-and-mouth disease. FOOD SECURITY, 7 (2), pp.291-302. https://doi.org/10.1007/s12571-015-0436-y.

Persistent Link:

http://hdl.handle.net/11343/116655 